\title{
Multimodal signs in (non)heteronormative discourse of transnational Hindi cinema: the case study of Hindi film Dostana
}

\author{
Snobra Rizwan \\ Institute of Linguistics \\ University of Graz, Austria \\ snobra.rizwan@edu.uni-graz.at
}

\begin{abstract}
This article conducts a detailed analysis of multimodal signifiers in a popular Hindi film Dostana (meaning friendship) with particular focus on film's (non) heteronormative and sexist system of signification. The signifiers that construct gender and sexual stereotypical worldview of the film are analyzed following Lazar's (2007) conception of feminist critical discourse analysis and Wodak's (2001) framework of Discourse Historical Approach which proposes three simultaneously functioning aspects of discourse, i.e. immanent, diagnostic and prognostic. The multimodal signifiers in the film are analyzed within Indo-Pakistani discursive context where patriarchal discourse does not seem to allow any cognitive pattern and mental model other than heteronormativity and heterosexual love and romance. In such discursive set-up, so-called deviant sexualities and gender roles struggle for voice, signifiers and representation. The prognostic critique of this article can be thought of as Positive Discourse Analysis (Martin, 2004), because eventually film's text offers some examples of how certain multimodal signs can be used to resist hegemonic patriarchal and heteronormative discourses which are considered common sense and natural by mainstream Hindi film audience.
\end{abstract}

Keywords: multimodal signifiers, Discourse Historical Approach, heteronormativity, popular Hindi film, Indo-Pakistani context 


\section{Introduction}

This article is about deconstruction and need for reconstruction of (non)heternormative and homoerotic discourse in a popular Hindi film Dostana (2008), set in a transnational context. It analyzes multimodal signifiers of this popular Hindi film in terms of its intersemiotic depiction of gender and sexuality. Theoretical approach combines Lazar's (2007) Feminist Critical Discourse Analysis insights which is considered to be at 'nexus of critical discourse analysis and feminist studies' (2007: 141), Foucault's (1972, 1978, 1980) discursive approach which correlates power, knowledge and meaning in relation to history and historical events and Wodak's (2001) Discourse Historical Approach because it takes into account contextual, textual and prognostic aspects of discourse. Under examination is complex interlocking of multimodal semiotic resources employed by filmmakers within discursive struggle of heteronormativity in IndoPakistani historic-socio-cultural scenario where homosexual discourses are finding their way stealthily yet gradually.

The representation of homosexuality is not an altogether new and novel idea for Indian cinegoers. Indian cinema has long offered glimpses of alternative sexualities, though in the negative and restricted terms. Bollywood cinema is known for its caricature of gay men and lesbians. There are countless films (such as Gulam 1998) featuring effeminate men who lust after the macho protagonists. It is in film Dostana that the representation of alternative sexualities seems to deconstruct the normative ideologies about (non)heteronormativity for the first time. Thus the "film can be considered the first film in mainstream Hindi cinema with direct homosexual references throughout as one of the central threads of its narrative while also achieving mainstream global box office success" (Durdah, 2012: 44). Directed by Tarun Mansukhani and produced by Karan Johar, the film associates "non-heteronormative male sexualities (usually coded as gay) with western and diasporic (as opposed to indigenous and traditional) sexualities" (Desai and Neutill, 2013: 238). Two of the protagonists of the film, Sam and Kunal, are heterosexual men who pretend to be gay in order to get an apartment owned by a beautiful straight young woman Neha. This romantic comedy targets homophobic, heterosexual audiences with implied plea for acceptance and tolerance for homosexuality. As rightly put forth by Srinivasan (2013), the film

may have been a cynical appropriation of an increasing public discourse on sexuality for the purpose of comedy, but the film has an internal mechanism of destabilizing dominant meanings. In this farcical tale of two men pretending to be gay, a queer reading could well mean they are not really pretending. They are straight only for textual purpose: the film speaks a different language as we are constantly asked to take in Sam and Kunal's (Abhishek Bachchan and John Abraham) togetherness. While using stereotypes to draw nervous laughs about the threat of homosexuality, the film also turns them upside down (Srinivasan 2013: 203).

There are multiple overlapping aims of this article. The first is to investigate the way Dostana tends to challenge all-pervasive heteronormative and homophobic discourse in 
Indian Sub-Continent context and calls for reconstruction of an alternative non-heteronormative discourse. Under the cloak of homophobic characterization, it attempts to portray homosexuals as normal, warm and best friends to heterosexuals. The second aim is to explore discursive reformative mechanism of signifying practices in film's overall discourse paradigm. Thus, following Discourse Historical Approach (Wodak, 2001, 2005), this study explores three interconnected aspects of discourse: Immanent, Socio-diagnostic and prognostic. In this study 'immanent critique' of the text has been connected with signifying practices internal to the film's discourse and text structure. As Wodak (2005: 68) suggests, immanent critique aims at "discovering inconsistencies, (self) contradictions, paradoxes, and dilemmas" in text's signifying practices (see section 6.1 below). The second aspect 'socio-diagnostic' critique (see section 6.2 below) reveals "background and contextual knowledge" of the text and embeds signifying structure of the text "in a wider frame of social and political relations, processes and circumstances" (Wodak, 2005: 68). The third and last aspect, "prognostic critique' (see section 6.3 below) has to do with overall message of the text which in Discourse Historical Approach's conception should contribute to "transformation and improvement of communication ... for example guidelines for avoiding sexist language use" (Wodak, 2005: 68).

In addition to this, the aims go towards Critical Discourse Analysis's aim of analyzing social practices and contributing to social change regarding perception of (non)heteronormative paradigms of gender and sexuality. According to Stibbe (2013), "in conducting research into pressing social issues as this the researcher has his or her own interests and agenda. As Fairclough (2001: 4) points out, these need to be taken into account in the analysis to ensure that it is rigorous and scientifically conducted" (2001: 115). The concern of this research is about homophobic and heteronormative attitude of sub-continent's patriarchal mind set which dismisses anything challenging its hegemonic norms as deviant, ridiculous and unworthy of serious consideration. Hindi films with their all-pervasive socio-cultural influence on general populace (Kasbekar, 2006) presumably have the power to disseminate and popularize certain discourses regarding gender and sexuality to the extent that they appear naturalized and commonsense. This research therefore is interested in counter-hegemonic versions of reality disseminated and popularized through film discourse like that of Dostana. Implicitly, this film calls heteronormative and patriarchal values of Sub-continent's socio-cultural set-up into question and opens up alternative ways of conceptualizing gender and sexuality in society. At the same time, it cannot be denied that this film presents women as a sex object repeatedly and portrays many gender and sexual stereotypes. In its defense, it could be argued that this has been done on purpose to ensure wider mass viewership and make this film's message reach out to wider audiences.

Wodak's (2001) notion of prognostic critique is quite apt to describe overall discourse strategy and paradigm of this film. In the end the message of the film becomes very clear. It calls for transformation and improvement of gender and sexuality related attitude. The way this film's discourse attempts to open up alternative ways of 
conceptualizing gender and sexuality in society makes it fall in the bracket of Positive Discourse Analysis (Martin, 2004), which functions to bring about hope and change and make this world a better place.

\section{2. (Non)heteronormative and (anti)patriarchal representations in transnational Hindi cinema}

Hindi cinema or Bollywood has undergone a metamorphosis as far as representation of gender and sexuality is concerned, especially in the case of narratives set in transnational contexts. Ever since its emergence, Bollywood's distinction from Hollywood remains noteworthy. According to Rosie Thomas (cited in Kaur and Sinha, 2005):

...Indian cinema has throughout its long history evolved as a form which has resisted the cultural imperialism of Hollywood : the form has undergone a continual change there has both been inspiration and assimilation from Hollywood and elsewhere, but thematically and structurally, Indian cinema has remained remarkable distinctive (2005: 15).

Like any other commercial artifact, the predominant themes and structures of mainstream Hindi cinema have always been mass oriented. From 1948 to the present, Hindi cinema has been formulating gendered and sexual subjects as incommensurability which is represented when a new making of historic-socio-cultural (non)heteronormative subject is attempted. Though transition in subjectivation in mainstream film representations is not that ground breaking, it is made to emerge when audiences' aesthetics are in tune with it. Thus, the notions of gay friendship were quite unheard of in early decades of Hindi cinema. Though the togetherness of male characters from film Dosti (1964) to Sholay (1975) provided a gay subtext with a unique dimension of heteronormativity of Hindi cinema, but the interpretative paradigm of the audience perceived it within the limits of their mental modals. It could be argued that through such male bonding in mainstream films sub-continents' general viewership was led to believe that a strong self-sacrificing male friendship could be a viable stand-in for a queer love match (Bhattacharya, 2013).

In the $16^{\text {th }}$ century, the signifier 'queer' used to stand for something strange, odd, peculiar and eccentric etc. Gradually, the sense of the term 'queer' shifted and in $19^{\text {th }}$ century it stood for 'transgression' and more recently by the end of the $19^{\text {th }}$ century the word is taken as a derogatory term for a male homosexual (Cheng, 2014: 155). This negativity still persists in Indian sub-continent's collective consciousness and could be traced in representation of transgressed or alternative sexualities in popular Hindi cinema. Halperin (1997) has said that the term does not refer to something particular. According to him whatever is at odds with the mainstream, supposedly legitimate, and dominant could be regarded as 'queer'. As this study deals with the aspects of gender and sexuality related cinematic representations, it views 'queerness' connected with these particular senses. In the 21st century, deviant, non(mainstream) and repressed gender and sexual identities (or 'queerness') emerge in South Asian diasporic 
heteronormative popular Hindi film narratives. "Ostensibly heteronormative films depict love between men in transnational spaces reincarnating South Asian liminalities as viable diasporic masculinities" (Bhattacharya, 2013: 17). Thus, discourse in Hindi films remained strictly adhered to religious ideals of heterosexual masculinities and femininities over six decades. It is only in twenty first century that liminal representations of non-heteronormativity made their way through mainstream Hindi film discourse. Still, such representations were accepted when looked at through a comic lens focused at a diasporic, westernized Indian community.

\section{Critical discourse analytical approaches}

Critical discourse analysis (CDA) is generally considered as one school but one must be aware of the fact that there are considerable differences between various approaches within critical discourse analysis. Generally a critical discourse analyst has to draw on more than one of these approaches. The reason for this multiplicity of approaches is that Critical Discourse Analysis was founded by the insights of five academics (i.e. Teun van Dijk, Gunther Kress, Theo van Leeuwen, Norman Fairclough and Ruth Wodak). All of them "saw a role for the critical linguistic analysis of language use in institutional and interpersonal settings to study the interrelation between discourse and society, and to create social awareness and empowerment" (CADAAD, 2014: paragraph 2). The following paragraph gives a brief overview of some of the significant critical discourse analytic approaches presented by above-mentioned analysts.

Fairclough $(1992,2001)$ 's conception of discourse and the social is poststructuralist and he is interested in the dynamic role of discourse in social change. Against this, van Dijk comes up with a social constructivist approach which has cognitive dimensions (e.g. 1991, 1993, 1997). Unlike Fairclough (1992, 2001) van Dijk does not understand power in Foucault's sense as productive, but he understands power in terms of abuse. On the other hand, Van Leeuwen's (1993) approach aims to provide a linguistic realization of sociological categories of representing people and Wodak's Discourse Historical Approach (DHA) [as an elaboration and extension of Critical Discourse Analysis] analyzes the change of discursive practices over time and in various genres. Notwithstanding these differences, critical discourse analytical approaches do have important characteristics in common as all draw on Foucault's discourse theory (1972, 1978 and 1980). All of them "see discourse as partly constitutive of knowledge, subjects and social relations. At the same time, they try to do a discourse analysis which is text oriented, that is, they try systematically to analyse language use as social practice - actual instances of language use - in relation to the wider social practice of which the discursive practice is part" (Jørgensen and Philip, 2002: 91).

As mentioned earlier, in this paper (non)heteronormative and (non)sexist system of signification of film Dostana has been studied critically in order to unravel certain gender and sexuality related signifying practices. These signifying practices could make sense only if Critical Discourse Analysis's stance of social inequalities and dialectical relationship between language and social reality (Fairclough, 2001) is merged with 
Discourse Historical Approach's levels of contexts, i.e. intertextuality and interdiscursivity, the extralinguistic social level and the sociopolitical and historical context of a particular text (Wodak and Meyer, 2009; Wodak and Reisigl, 2009; Richardson and Wodak, 2009a; Richardson and Wodak, 2009b).

This paper brings together these perspectives of critical Discourse Analysis along with feminist perspective. Following Critical Discourse Analytical theoretical stands, feminist model of Critical Discourse Analysis has been proposed by Lazar (2007). Feminist Critical Discourse Analysis shows persistence of gender inequalities in certain heterogeneous forms which make themselves evident in different institutional, cultural and historical contexts. Thus connected with multiple critical discourse analytical approaches, this study is quite relevant in exploring present day structures and ideologies of gender and sexualities in Indo-Pakistani mainstream context. The film under analysis in very significant in this regard because it challenges presumably commonsensical or hegemonic assumptions of gender and sexual identities in subcontinent's context and somewhat persistent limits imposed upon gender roles and (non)heteronormativity. These elements get divergent representations in film's hierarchically gendered discourse order inter-twined with various structures of domination where multiple layers of identifications are discursively (re)produced, negotiated and contested.

\section{Multimodal Signifiers in Films}

The turn from verbal culture to visual culture saw its rise from the study of static images as an important signifier (Barthes, 1991). This interest kept growing and resulted in the form of further exploration of the 'grammar' of visual design (Kress and Leeuwen, 2006) and the systemic-functional investigation of sculptures, paintings and architecture (O'Toole, 1994). From exploration of static images as a communicative tool, the interests of the theorists (Bateman, 2008; O' Halloran, 2004, 2005; O' Halloran and Smith, 2011) shifted to the study of multimodal texts with multiple semiotic resources and the way both linguistic and non-linguistic signifiers serve the communicative purpose. Film text has always been considered a complex interplay of multiple semiotic resources which according to Baldry (2004) could effectively be studied by the incorporation of computer technology. For this purpose Baldry and Thibault (2001) designed Multimodal Corpus Authoring (MCA) system which provides possibility of analyzing multimodal discourse in a pedagogical context. In this connection O'Halloran (2004), further concentrates on temporal and spatial dimension in visual semiosis in film text and expresses concerns over difficulties in capturing dynamic interplay of various semiotic modes.

As far as this study is concerned, it owes its design from Stibbe's (2013) framework of multimodal metaphor analysis where he delineates different components of a multimodal metaphor in a documentary film The Corporation. In this paper, a range of signifying strategies of film discursive structure have been analyzed not for metaphors but for certain multimodal signs which signify (non)heteronormative gender and sexual 
representations through the interplay of various semiotic modes. In this film, a range of individual and interconnected multimodal signifiers contribute in constructing larger discourse structures where multiple signifiers end up in particular overtones or undertones and convey a polarized ideological position regarding gender and sexuality. This position moves from extreme sexist and homophobic representations to gradual acceptance for homosexuality and non-sexist representations.

Table 1 on the following pages gives detailed analysis of films' title Dostana (meaning friendship) along with description of how film's title is connected with overall discursive structure of the film. Before having a look at Table 1, it is perhaps important to have an overview of Film Dostana's plot.

\section{Overview of Hindi film Dostana's plot}

Nurse Sameer Kapoor and photographer Kunal Chopra pretend that they are gay lovers because they want to rent an apartment. They lie about their sexual identity because the owner of the apartment, beautiful young woman Neha Melwani, did not want to share the apartment with men. Both Kunal and Neha fall in love with Neha but Neha falls in love with her boss Abhimanyu Singh. Meanwhile, amidst many twists and turns of the plot, Sameer's mother also discovers that her son and Kunal are living as a gay couple and is utterly displeased. Sameer and Kunal try to tell her the truth, but of no avail. Finally, on Neha's plea Sameer's mother accepts her son's gay identity.

When Kunal and Sameer come to know about Neha and Abhimanyu's growing attraction, they plan to sabotage their relationship. They portray Neha in a negative way in front of Abhimanyu's five year old son Veer, and Veer starts hating Neha. Resultantly, Abhimanyu and Neha break up. At the same time Kunal and Sameer also disclose their heterosexual identity to Neha, but they are unaware of Neha's breakup with Abhimanyu. Neha is utterly displeased with them and tells them both to leave her apartment immediately.

Few months later Kunal and Sameer meet Neha at a fashion show and apologize for their lie. Abhimanyu also appears on the scene. Neha still displeased with them, tells them that Abhimanyu broke up with her, because Veer was uncomfortable with her. At this, Kunal and Sam reveal that how they poisoned Veer against Neha. Both Neha and Abhimanyu are infuriated. Kunal and Sameer climb on the stage and beg for forgiveness. Abhimanyu's anger suddenly subsides and he jokingly asks the men to kiss if they wish to get forgiveness for their manipulations. To win Neha's forgiveness, Kunal forcibly kisses Sameer at the last moment.

After two months, Neha is happily married to Abhimanyu. She, while sitting with Kunal and Sameer on the apartment's balcony asks whether they ever felt anything for each other while pretending to be gay. Neha leaves, and Kunal and Sameer think about the kiss.

Other than these characters, there are two minor yet interesting and worthmentioning gay characters in the film. One of them is M, Neha's Indian boss before Abhimanyu, who is a stereotypical representation of homosexuals with feminine 
demeanor and effeminate body language. The second important representation is that of a white gay officer from the US immigration office, where Kunal and Sameer apply for residence permission as a gay couple. The officer comes for a surprise inspection of Sameer and Kunal at Neha's place where $M$ is also invited. Thus all these characters, real homosexuals and fake homosexuals, happen to share screen in one of the most hilarious sequences of the film.

It is pertinent to mention at this point that songs are an important ingredient of a Hindi film and are profoundly integrated in film's texture. Hindi films make use of a number of devices for incorporating songs in a film. Song inclusion in the films is often "non-linear and story usually pauses, though not always completely, while song sequence takes place" (Morcom, 2007: 239). Hindi film songs text is very dense and rich in meaning. The film songs text and signifying practices are not always in sync with film's overall mood and rhetoric structure. Film Dostana incorporates six songs into its narrative. Five out of six songs celebrate heterosexual love between male and female characters. One song Maa da ladla bigad gaya (Mama's boy has gotten spoilt) is humourous and funny which voices discomfort of a gay son's mother over her son's gay identity. The songs' text has not been analyzed for multimodal signifiers in this paper, because analyzing that amount of text would be out of scope of one paper.

Table 1: Analysis of Film's Title 'Dostana' as a Multimodal Signifier

\begin{tabular}{|l|l|}
\hline $\begin{array}{l}\text { Components of a } \\
\text { Multimodal Sign }\end{array}$ & Description \\
\hline 1. Immanent Critique & $\begin{array}{l}\text { Here, the focus is on diversity and multiplicity of signifieds } \\
\text { for signifier } \text { dostana which (signifieds) seem inconsistent and } \\
\text { contradictory at times. }\end{array}$ \\
\hline 1.1 Signifier & $\begin{array}{l}\text { Dostana (repeatedly represented visually through togetherness of } \\
\text { two male principal characters). }\end{array}$ \\
\hline & $\begin{array}{l}\text { Throughout the film, verbal representation of signifier 'dostana' } \\
\text { happens only once. }\end{array}$ \\
\hline & $\begin{array}{l}\text { Friendship. Urdu/Hindi word dostana is a variant of word dosti } \\
\text { which after this film is quite often associated with gay relationship } \\
\text { by regular Hindi film viewers. }\end{array}$ \\
\hline & $\begin{array}{l}\text { The verbal manifestation of dostana signifies pure and true } \\
\text { friendship between men and women, but overall system of } \\
\text { signification of the film suggests otherwise and restricts its } \\
\text { meaning to gay relationship only. }\end{array}$ \\
\hline 1.3 Visuals & $\begin{array}{l}\text { Two young men who pretend to be gay lovers are forced to stay } \\
\text { together in different circumstances. }\end{array}$ \\
\hline & $\begin{array}{l}\text { At times, men who pretend to develop gay dostana try to behave } \\
\text { like women through their body language; thus film text also } \\
\text { expresses a misogynist undercurrent. }\end{array}$ \\
\hline & $\begin{array}{l}\text { At times, they (men) really find their relationship stronger than } \\
\text { their attraction for the woman in their life. }\end{array}$ \\
\hline When verbal narration (see 2.1 section of Table 1) of sign dostana \\
\hline
\end{tabular}




\begin{tabular}{|c|c|}
\hline & $\begin{array}{l}\text { happens ( } 1 \mathrm{~h} 06 \mathrm{~m} 42 \mathrm{~s}) \text {, Sameer and Kunal physically push Neha } \\
\text { aside and hug each other. }\end{array}$ \\
\hline 1.4 Music & $\begin{array}{l}\text { In most of the mises en scène, music has humourous and comic } \\
\text { tone implying homophobia except twice where it implies male } \\
\text { friendship which is not homoerotic ( } 1 \mathrm{~h} 06 \mathrm{~m} 42 \mathrm{~s} \text { and } 2 \mathrm{~h} 05 \mathrm{~m} 51 \mathrm{~s}) \text {. }\end{array}$ \\
\hline \multirow[t]{3}{*}{1.5 Polarity } & From negative to positive: \\
\hline & $\begin{array}{l}\text { Most of the visual representations of male friendship are comic } \\
\text { with homophobic undercurrents, obviously with negative } \\
\text { connotations. }\end{array}$ \\
\hline & $\begin{array}{l}\text { When film reaches near climax, the tone changes and suddenly } \\
\text { gay dostana is eulogized as something positive and good. }\end{array}$ \\
\hline $\begin{array}{l}\text { 2. Socio-diagnostic } \\
\text { Critique }\end{array}$ & $\begin{array}{l}\text { Vocalization, meaning range, overtones/undertones and polarity of } \\
\text { linguistic sign Dostana could occur and make sense only in a } \\
\text { transnational Indian context, where characters are free from } \\
\text { discursive bondage of their local context. }\end{array}$ \\
\hline 2.1 Vocalization & $\begin{array}{l}\text { Kunal to Neha and Sam: (from 1h06m42s) You know guys, you } \\
\text { are right. I am happy and my life is truly perfect. That's only } \\
\text { because I have two of you in my life. Think about it, If you (Neha) } \\
\text { had married somebody and you (Sameer) had been shooting at a } \\
\text { beach in Miami, how would we have met? We three losers? } \\
\text { Whatever said and done, this friendship (dostana) is much more } \\
\text { rocking that any plan we might have had. Right? }\end{array}$ \\
\hline \multirow[t]{5}{*}{$\begin{array}{l}2.2 \text { Overtones/ } \\
\text { Undertones }\end{array}$} & Gay relationship \\
\hline & $\begin{array}{l}\text { Dostana entails male friendship, male bonding which is at the } \\
\text { brink of homosexuality and is ridiculed and made fun of by } \\
\text { straight people. }\end{array}$ \\
\hline & A heterosexual woman could be a friend to gay men. \\
\hline & $\begin{array}{l}\text { Straight men and women cannot make dostana, because it would } \\
\text { eventually result in sexual attraction. }\end{array}$ \\
\hline & (Contradiction, inconsistency and multiplicity of signifieds.) \\
\hline 3. Diagnostic Critique & $\begin{array}{l}\text { Characters' transformation and improvement of understanding gay } \\
\text { relationships happens in the narrative finally. }\end{array}$ \\
\hline \multirow[t]{2}{*}{ 3.1 Message } & $\begin{array}{l}\text { Homosexuality is not something disgusting and aversive. It is like } \\
\text { other human bonding and not to be scared of. }\end{array}$ \\
\hline & $\begin{array}{l}\text { Women are not mere sex objects. When the bond of friendship } \\
\text { gets stronger, the male perspective to look at the women changes. }\end{array}$ \\
\hline
\end{tabular}

\section{Interplay of misogynist and heteronormative signifying practices in film's discursive structure}

The film opens with a song sequence where viewers are introduced to Kunal with his strictly straight sexual identity. Kunal emerges out of an ocean in yellow shorts at South Beach, Miami, and has some cozy time with women. In the same song, other protagonist Sameer is also introduced having fun in the company of women. After 
introductory song, film text keeps using multiple multimodal signs to establish Kunal and Sameer's straight identity for film's presupposed heterosexual viewers who supposedly are hegemonized product of heteroronormativity. Along with this, misogynistic and stereotypical depiction of women as a sex object also continues complementing overall discursive structure of film because film is narrated from male point of view. It is truly in accordance with Rubinfeld's statistics (cited in Rasche, 2006) about romantic comedies' narrative structures which 'are narrated from a male point of view. According to Rubinfield's research (Rasche, 2006) 97\% of all "purist plots" are depicted from male point of view and only $3 \%$ are depicted from female one' (2006: 8).

Let us consider the following section now which provides the immanent critique of the film's multimodal text.

\subsection{Immanent Critique}

It is important to mention at this point what immanent critique actually aims at discovering in this study and what aspects of discourse it really stands for. Immanent critique stands for inherent, immediate and internal meaning making potential of an utterance or a discrete linguistic item. The semantic field (of utterance or discrete linguistic item) thus reached at could contain inconsistent and contradictory meaning relations sometimes. Taking insights from Blackledge (2005) it could be argued that immanent aspect of discourse include lexical solidarities, collocational particularities, connotations, implications and presuppositions. A discourse historical and feminist reading of the text reveals a number of multimodal signifiers (see Table 2) in film's immanent structure which would be discussed below in relation to film's heteronormative and patriarchal discourse. Most of these signifiers have negative connotation and contain heteronormative, homophobic and misogynist entailments.

If we have an overview of all the signifiers listed in Table 2, it is quite obvious that most of them exhibit a kind of lexical solidarity. They seem to be closely connected to each other as far their connotations, implications and presuppositions are concerned. The signifiers (nurse, baby, witch) used to signify homosexual men deny them the typical characteristics of manliness and masculinity. As it is evident from the table, the sign 'nurse' happens four times in the narrative, and at all four occasions the characters are unable to grasp the idea of a male nurse. At one point, a white American man who is a patient at Harvard Medical Centre where Sameer works as a nurse asks him again and again why he adopted the profession of a nurse:

Patient to Sameer (from 09m10s): So you are actually a nurse and you studied five years to become one, a nurse. Why? I mean you could've studied the same and become a doctor. Why a nurse?

As narrative unfolds, it becomes obvious that being a nurse could be an inappropriate profession for a 'man' but not for a 'gay', because unlike straight people Neha's gay boss $\mathrm{M}$, becomes quite excited when Sameer tells him that he is a nurse: 
M to Sameer (from 48m00s): Neha was telling that you are new here in Miami.

Sameer: Actually I am from London and work in Harvard Medical Centre.

M: Doctor, Doctor

Sameer: Nurse, Nurse

M: My temperature is rising, maybe because of wine. Let's have some fun.

The excitement of $\mathrm{M}$ on hearing Sameer's profession makes 'nursing' an appropriate profession for a gay but not for a 'real man'. Then nurse also collocates with short skirt twice in the text, and at both the occasion Sameer is ridiculed because he is conceptualized working as a nurse in a short skirt. Anything feminine in men's behavior, attitude and practices, reduces their quotient of masculinity and makes them a laughing stock in the eyes of the heteronormative world. Thus, 'nurse' becomes one of the important signifiers in the film, and its potential signified could be reached at only by observing the intersemiotic working of all three modes of its representation. Similarly 'baby' (signifying women, girls) in the text stands in contrast with 'baba' (signifying men, boys). While disclosing his and Kunal's sexual identity, Sameer tells Aunty (17m49s): We are 'babies'. It once again denies masculine identity to homosexuals.

The representation of society's negative attitude towards homosexuals reaches its culmination when Sameer's mother calls M a 'witch' who is bewitching his son to be his partner. Once again it is a female appellation which is considered apt to represent supposedly evil and unnatural effects of homosexuality. Such negativity does not stop here; it continues and is represented in form of multiple multimodal representations such as 'dirty boys', 'bad dream', 'brothel', 'fake life' and 'mistakes'. All these strategies signify gay relationship in a negative light. Thus in mainstream conception, gays are dirty boys; their life is not real life; homosexuals live a fake life; their sexual inclination is a 'mistake' and 'a bad dream'.

Another signifier worth mentioning is 'jiggery poo' [(6) in Table 2]. This term of address has been invented by Sameer in the film, because he does not find terms like 'darling', 'beloved' and 'love' appropriate to address Kunal, his presumed gay partner. Invention of this terms hints at politics of representation and struggle for meaning in a hegemonized discursive social set-up, where un-privileged groups are denied voice and representation. Thus, current system of signification and modes of representation in Urdu/Hindi seem to lack system of signification for homosexual relationship. It becomes obvious with Neha's Aunty's description of homosexual men as 'modern kind of men', the kind which according to her limited perception did not even exist when she was young. So, how could a society whose half of the population was oblivious of the existence of same-sex relationship some twenty to thirty years ago could have evolved signifying structures for the representation of such relationship. This point would be further elaborated in the next section of the paper (see section 6.2).

As Table 2 indicates, at most of the occasions, background music and sound effects do not support different representations. It is use of paralinguistic features and facial expressions which do the needful and make multimodal representations effective. In the 
light of Table 2, 'nurse' 'jiggery poo' and 'dirty boys' are strongest signs of discourse's immanent structure because they get multiple representations and are realized three, three and four times respectively.

Table 2: Immanent Critique of Film Dostana's Discourse-Internal Structure

\section{Multimodal Signifiers}

(2.1) Nurse

(09m10s, 14m21s, 26m39s 48m00s) $(14 \mathrm{~m} 23 \mathrm{~s}, 26 \mathrm{~m}, 40 \mathrm{~s})$

(2.3)Baby

(Women)

$(17 \mathrm{~m}, 49 \mathrm{~s})$
(2.2)ShortSkirt

\section{Modes of Representation}

Verbal: Multiple manifestations of signifier in sexist manner Visual: Sameer's representation in male nurse uniform happens twice Music: Cheerful and suggestive music

Verbal: Nurse and short skirt collocate Visual: Suggestive laughter and smirks at the idea of male nurse in short skirt Music: No music Verbal: Gays referred to as 'baby' implying women

Visual: No particular visual representation Music: Negative comic, suggestive music

Verbal: Neha's Aunty (a representative of domestic, not well-educated Indian women) thinks that

(2.4)Modern Type of Men $(22 \mathrm{~m} 28 \mathrm{~s})$ homoeroticism did not exist in the past, some twenty Negative

\section{Polarity}

Negative

Negative to thirty years ago in her perception. Visual: No particular visual representation Music: No music

(2.5)Girlfriend and Verbal: The gay partners conceived in terms of

Boyfriend heteronormativity Visual: No particular visual Neutral
$(22 \mathrm{~m} 37 \mathrm{~s}) \quad$ representation Music: No music

\section{(2.6)Jiggery Poo}

(Invented

Appellation for a

Gay boyfriends)

(28m53s)

Verbal: Uttered by Sameer in female tone Visual:

Sameer behaving and talking like a woman Music: Neutral

(1h17m14s)

Funny, stereotypical romantic music

$(1 \mathrm{~h} 34 \mathrm{~s} 05 \mathrm{~s})$

(2.7)Dirty boys

$(15 \mathrm{~m} 39 \mathrm{~s}, 37 \mathrm{~m} 50 \mathrm{~s}$,

$38 \mathrm{~m} 16 \mathrm{~s}, 39 \mathrm{~s} 07 \mathrm{~s}$,

$46 \mathrm{~m} 04 \mathrm{~s}, 46 \mathrm{~m} 26 \mathrm{~s})$

(2.8)Bura Sapna Verbal: Uttered by Sameer's mother Visual: Realized

(Nightmare)

by Sameer's facial expression showing disbelief

Negative

$(50 \mathrm{~m} 05 \mathrm{~s})$ Music: No music

Negative

(2.9)Dayan (witch) Verbal: Uttered by Sameer's mother Visual: Neha's $(51 \mathrm{~m} 12 \mathrm{~s})$

gay boss: A comic figure Music: No Music

Negative 
(2.10) Jhoot ki zidagi (Fake life, living a lie) (50m42s)

(2.11)KunjarKhana (Brothel) (51m02s)

(2.12)Ghaltian

(Mistakes)

$(52 \mathrm{~m} 39 \mathrm{~s})$
Verbal: Uttered by M (Neha's gay boss) Visual:

Comic revelation of gays' life who are unable to reveal their sexual identity Music: No Music
Negative

Verbal: Uttered by Sameer's mother Visual:

Sameer's mother in tears while uttering this signifier Negative Music: No Music

Verbal: Uttered by Sameer's mother Visual:

Sameer's mother in tears while uttering this signifier Negative Music: No Music

Summing up it could be argued that Table 1 given above enlists all the important signifiers which have potential to contribute in the immanent critique of the film's discourse. Though these signifiers make complete sense through simultaneous and coordinated working of their multimodal realizations but it is the verbal mode which seems to be the most effective. The inherent negative polarity of the signs is communicated to the audience through the subtle working of visual and aural signs along with verbal signs. Visual signs comprising of gestures, body language and facial expressions of the characters add certain connotations and implications to the verbal signs; and music, if accompanied with verbal and visual signs, serves to create certain presuppositions in the text recipients or film audiences regarding overall semantic content of the discourse. In this way intersemiotic texture of the film operates and leads one to comprehend and decode its discourse-internal structure.

\subsection{Socio-diagnostic critique}

The overall system of signification of the film's (non)heteronormative and(non)sexist discourse could be unveiled effectively only if manipulative and mystifying character of discursive strategies is exposed in relation to the background and contextual knowledge of certain discourse practices. In this study, the analysis of background and contextual knowledge of text takes into account two levels of context (borrowed from Wodak 2001: 67) which include:

- 'Intertextual and interdiscursive relationship between utterances'

- 'The broader sociopolitical and historical contexts, which the discursive practices are embedded in and related to (grand theories)'

Table 3 given below makes an attempt to elaborate interdiscursive and intertextual nature of love and romance related discourse of Indian-subcontinent. This table is quite extensive and provides socio-diagnostic critique of the film taking three aspects into consideration: Vocalization of discourse (which provides an idea about which character uttered the lines in the film and in what manner), Overtone/ Undertone (which provide both obvious and implied/inherent meanings of given discourse instances) and finally the modes of signification (which give a clue about intertextual working of film's text). 
Table 3: Socio-Diagnostic Critique of Film Dostana's Transnational Discourse

\begin{tabular}{|l|l|}
\hline $\begin{array}{l}\text { Vocalization of } \\
\text { Discourse }\end{array}$ & $\begin{array}{l}\text { Sameer to Kunal: (from16m17s): [Explanatory tone] In } \\
\text { order to get that house, if we have to lie to an old baby that } \\
\text { we are gay, what difference does it make? Voice-Over: } \\
\text { (from 20m45s) Aunty, Aunty You drive me crazy.. }\end{array}$ \\
\hline Overtones/Undertones & $\begin{array}{l}\text { Voicing of existing taboo against sex for older women To } \\
\text { young men, lying about one's sexual identity to older } \\
\text { women does not matter at all }\end{array}$ \\
\hline Modes of Signification & $\begin{array}{l}\text { Linguistic and paralinguistic signs Visualized through } \\
\text { caricaturing bad fashion taste of Aunty A song (voice-over) } \\
\text { caricaturing aunty }\end{array}$ \\
\hline
\end{tabular}

\begin{tabular}{|l|l|}
\hline $\begin{array}{l}\text { Vocalization of } \\
\text { Discourse }\end{array}$ & $\begin{array}{l}\text { Aunty to Neha [confidingly]: (from 22m20s) They both } \\
\text { aren't what we are ...It was not like that in our old days. In } \\
\text { our days guys used to like girls. (from22m20s) }\end{array}$ \\
\hline Overtones/Undertones & $\begin{array}{l}\text { Homosexual relationship being discussed as a deviation and } \\
\text { non-normalcy Celebration and eulogizing of 'good old days' } \\
\text { of heteronormativity 'Othering' of homosexuals through } \\
\text { their exclusion from in-group }\end{array}$ \\
\hline Modes of Signification & Linguistic and paralinguistic signs by Aunty \\
\hline
\end{tabular}

\begin{tabular}{|l|l|}
\hline $\begin{array}{l}\text { Vocalization of } \\
\text { Discourse }\end{array}$ & $\begin{array}{l}\text { Sameer to Aunty [In confiding, meaningful explanatory } \\
\text { tone]: (from18m00s) Kunal and I are together. We are with } \\
\text { each other you know. Kunal is my special friend. My most } \\
\text { special friend ... }\end{array}$ \\
\hline Overtones/Undertones & $\begin{array}{l}\text { Lack of signifiers to represent gay relationships } \\
\text { inoffensively in Hindi/Urdu discourse Underlined word } \\
\text { show struggle for representation and lack of signifying for } \\
\text { same-sex love }\end{array}$ \\
\hline Modes of Signification & Linguistic and paralinguistic signs Subdued, comic music \\
\hline
\end{tabular}

\begin{tabular}{|l|l|}
\hline $\begin{array}{l}\text { Vocalization of } \\
\text { Discourse }\end{array}$ & $\begin{array}{l}\text { Aunty to Sameer and Kunal [Interrogatory tone] (26m50s) } \\
\text { Since when have you been hero and heroine? }\end{array}$ \\
\hline Overtones/Undertones & $\begin{array}{l}\text { Another representation of lack of signifiers for gay partners } \\
\text { in Hindi/Urdu Use of heteronormative signifiers for gay } \\
\text { partners (underlined words) }\end{array}$ \\
\hline Modes of Signification & Linguistic and paralinguistic signs \\
\hline
\end{tabular}

\begin{tabular}{|l|l|}
\hline $\begin{array}{l}\text { Vocalization of } \\
\text { Discourse }\end{array}$ & Sameer to Aunty and Neha: (from 27m20s) [In feminine, \\
\hline
\end{tabular}




\begin{tabular}{|c|c|}
\hline & $\begin{array}{l}\text { love-struck tone] } \\
\text { We met in Venice. I met Kunal in Venice the first time. In } \\
\text { that first meeting, Kunal showed me a thousand dreams. I } \\
\text { felt as if I was standing and ground below was moving. My } \\
\text { heart beat faster and I gasped for breath. Was this my first } \\
\text { love? Next few days fate made us come across each other } \\
\text { again and again, at times here, at times there. Finally I } \\
\text { gathered courage and said something to him, 'O tormentor, } \\
\text { are you following me? 'Gosh, Oh no why didn't my tongue } \\
\text { cut into pieces? He left so suddenly that I never saw him } \\
\text { again. I searched for him a lot. I didn't even know his name } \\
\text { to call out. My (pritam) darling, my beloved (premi), my } \\
\text { jiggery poo'??? But he was nowhere to be found. Tired, } \\
\text { defeated, yearning for love (pyar ka pyasa), I returned to my } \\
\text { hotel where a letter was waiting for me. My first love letter, } \\
\text { in which it was written, at seashore my heart calls out to } \\
\text { you, Oh. So naughty. Immediately, I put on my Gucci shoes } \\
\text { and Armani jacket and set off towards my destiny. Kunal } \\
\text { was on other side of seashore. My feet trembled when I } \\
\text { moved towards him. Bathed in moonlight, with a rose } \\
\text { clenched in his teeth, there stood Kunal, Oh Kunal ... } \\
\text { Neha: So sweet I think I am gonna cry. }\end{array}$ \\
\hline Overtones/Undertones & $\begin{array}{l}\text { Narration of falling in love of gay partners in heterosexual } \\
\text { romance narrative structural paradigm from a women's point } \\
\text { of view (in order to create humour) } \\
\text { All the underlined chunks are stereotypical hackneyed, } \\
\text { repeated signifiers for description of heterosexual love in } \\
\text { Indo-Pakistani heteronormative romantic discourse } \\
\text { The underlined signifiers represent woman's point of view } \\
\text { who is shy, timid, lacks courage etc. }\end{array}$ \\
\hline Modes of Signification & $\begin{array}{l}\text { All three modes of signification along with paralinguistic } \\
\text { features interact in this sequence to create an exaggerated } \\
\text { comic effect. Feminine gestures and colourful cloths and } \\
\text { shoes of Sameer. Romantic music continues throughout }\end{array}$ \\
\hline
\end{tabular}

\begin{tabular}{|l|l|}
\hline Vocalization of & $\begin{array}{l}\text { Sameer to Kunal and Neha: (from34m50s) [Annoyingly] } \\
\text { (Miscourse }\end{array}$ \\
$\begin{array}{l}\text { (Mour down is like full on hard core Punjabi ham scene... Tears } \\
\text { everything... Day and night, she keeps harping the same } \\
\text { string, 'why don't you get married? Mrs. Khanna's cousin } \\
\text { from Amritsar has two daughters. It's a buffet, choose } \\
\text { whichever you want'. }\end{array}$ \\
\hline
\end{tabular}




\begin{tabular}{|l|l|}
\hline Overtones/Undertones & $\begin{array}{l}\text { Gay relationship of children inconceivable for Indo- } \\
\text { Pakistani parents Mothers concern about children's } \\
\text { marriages Mothers attempt for match-making of their } \\
\text { children In transnational Indian communities children are } \\
\text { annoyed with traditional attitude of parents }\end{array}$ \\
\hline Modes of Signification & $\begin{array}{l}\text { Use of linguistic and paralinguistic clues by Sameer for } \\
\text { representation of his mother from a a diasporic Indian } \\
\text { child's point of view }\end{array}$ \\
\hline
\end{tabular}

\begin{tabular}{|l|l|}
\hline $\begin{array}{l}\text { Vocalization of } \\
\text { Discourse }\end{array}$ & $\begin{array}{l}\text { Sameer to Kunal and Neha: (from 36m50s) [Meaningful, } \\
\text { self-confident, explanatory tone] We are no less than other } \\
\text { men. We are like regular Gabbars, man. . Come on Kunal, } \\
\text { haven't you seen the film, Gabbar was gay. Neha: } \\
\text { (Spontaneous laughter) Kunal: Gabbar was not gay. }\end{array}$ \\
\hline Overtones/Undertones & $\begin{array}{l}\text { Gabbar: An intertextual reference to a Hindi film character } \\
\text { famous for his brutality, sadism and terror. }\end{array}$ \\
\hline Modes of Signification & Use of linguistic and paraliguistic signs \\
\hline
\end{tabular}

\begin{tabular}{|l|l|}
\hline $\begin{array}{l}\text { Vocalization of } \\
\text { Discourse }\end{array}$ & $\begin{array}{l}\text { Neha to M: (from39m50s) [Friendly and Lovingly] Darling, } \\
\text { You look gorgeous today. M: Only you know what I want to } \\
\text { hear in the morning. }\end{array}$ \\
\hline Overtones/Undertones & $\begin{array}{l}\text { Gays are like women who want appreciation and praise for } \\
\text { their looks and appearance }\end{array}$ \\
\hline Modes of Signification & $\begin{array}{l}\text { Use of linguistic and paralinguistic signifiers...Visually, use } \\
\text { of M's femininities for stereotyping gays M's introduction } \\
\text { wit cheerful fast music }\end{array}$ \\
\hline
\end{tabular}

\begin{tabular}{|l|l|}
\hline $\begin{array}{l}\text { Vocalization of } \\
\text { Discourse }\end{array}$ & $\begin{array}{l}\text { Sameer to Kunal: (47m20s) [confusedly and hurriedly] } \\
\text { Think like women, talk about his hair, what shoes he is } \\
\text { wearing... Think like a woman, Feel like a man. }\end{array}$ \\
\hline Overtones/Undertones & $\begin{array}{l}\text { Equating gays with women, } \\
\text { The strategies to please gay men: comment on their } \\
\text { appearance, Stereotyping women's topics of discussions }\end{array}$ \\
\hline Modes of Signification & $\begin{array}{l}\text { Paralinguistic features Visuals: Kunal's attempt to behave } \\
\text { like a woman }\end{array}$ \\
\hline
\end{tabular}

\begin{tabular}{|l|l|}
\hline Vocalization of & M to Officer and Sameer: (from 50m40s) [tearful, funny, \\
\hline
\end{tabular}




\begin{tabular}{|l|l|}
\hline Discourse & $\begin{array}{l}\text { feminine tone]How would she know? Living a lie, that too } \\
\text { for others, it hurts, it really really hurts. Until today, I } \\
\text { haven't told mummy and daddy that I, their Murli... }\end{array}$ \\
\hline Overtones/Undertones & $\begin{array}{l}\text { Gay children try to hide their sexual identity from their } \\
\text { Indian parents. A transnational context allows them voice } \\
\text { their stress and grief over this issue }\end{array}$ \\
\hline Modes of Signification & $\begin{array}{l}\text { Visually: Hugging and comforting each other...Silence after } \\
\text { underlined utterance }\end{array}$ \\
\hline
\end{tabular}

\begin{tabular}{|l|l|}
\hline $\begin{array}{l}\text { Vocalization of } \\
\text { Discourse }\end{array}$ & $\begin{array}{l}\text { Mother: ... (from 52m10s) [tearful and loud with great anger } \\
\text { and disgust] Oh God, grant me death. What are you } \\
\text { punishing me for, God? ...(Love) is not too blind to } \\
\text { differentiate between a guy and a girl...Stop it. Enough. I } \\
\text { am struck with grief... I won't listen to anything now. How } \\
\text { would you support me well... }\end{array}$ \\
\hline Overtones/Undertones & $\begin{array}{l}\text { Stereotypical religious discourse of praying: A typical way } \\
\text { of addressing God in Indo-Pakistan context at the sight of } \\
\text { utter discomfort and disillusionment Voicing of parents' } \\
\text { idea of their children supporting them in old age through } \\
\text { marrying and having children }\end{array}$ \\
\hline Modes of Signification & $\begin{array}{l}\text { Visually: Mother constantly staring at the ceiling while } \\
\text { talking to God... Linguistic and paralinguistic clues } \\
\text { continue }\end{array}$ \\
\hline
\end{tabular}

\begin{tabular}{|c|c|}
\hline $\begin{array}{l}\text { Vocalization of } \\
\text { Discourse }\end{array}$ & $\begin{array}{l}\text { Mother to Sam and Kunal: (from1h02m30s) } \\
\text { stereotypical, emotional, Indian mother style with } \\
\text { exaggerated motherly love and affection] } \\
\text { I bought these bangles for my daughter-in-law. Honestly I } \\
\text { don't know whether you are my (damad) son-in-law or } \\
\text { (bahoo) daughter-in-law? } \\
\text { Whatever you are, accepts these bangles as a gift from me. } \\
\text { And don't forget to observe Karva chauth fast for my son's } \\
\text { long life. I'll send you the (sargi) offerings. I am leaving him } \\
\text { in your care. I have brought him up with great love and care. } \\
\text { Take good care of him. Now hurry up and seek my blessing.. } \\
\text { May you live long and bear children... Okay Forget it. }\end{array}$ \\
\hline Overtones/Undertones & $\begin{array}{l}\text { A stereotypical household discourse in an Indian family } \\
\text { regarding a mother's wish to see her son's bride and }\end{array}$ \\
\hline
\end{tabular}




\begin{tabular}{|l|l|}
\hline & $\begin{array}{l}\text { advising her to carry on family traditions An amalgam of } \\
\text { social, domestic and religious discourses The words in } \\
\text { brackets have certain religious and socio-cultural } \\
\text { connotations which could be valued only in an Indian } \\
\text { context. Marriage, fasting, elders' blessings and offerings, } \\
\text { children and all the connected rituals are quite important in a } \\
\text { traditional Indian household. }\end{array}$ \\
\hline Modes of Signification & $\begin{array}{l}\text { Linguistic and paralinguistic clues continue The whole } \\
\text { linguistic chunk is followed by an emotional tear-jerker } \\
\text { Hindi film song about family ties }\end{array}$ \\
\hline
\end{tabular}

Twelve given instances (3.1 to 3.12 ) in Table 3 reveal interdiscursive and intertextual nature of love and romance related Indian-subcontinent discourse, where there is no place for atypical and deviant signs and representations. The whole sociocultural and religious paradigm of Indo-Pakistan constructs a patriarchal and heteronormative worldview where deviation struggles for voice and representation. Thus prevalent and dominant texts regarding aging, grand narratives of love and romance, religio-socio-historical discursive practices regarding institution of marriage and Indian family life and values all intertwine and weave a social order whose texture would resist anything unorthodox and unconventional. Table 3 shows many representations of this sort where unconventional and unorthodox depiction of characters have been done at the cost of their humiliation and grotesque and outlandish portrayals.

It could be observed in (1) (see Table 3), that young men would lie to Aunty about their sexual orientation only because she is old and not sexually attractive. She has been described as old and fashion disaster again and again in the narrative. Such perception of women is very deep rooted in Indo-Pakistani discursive set-up where 'after menopause a woman is no longer considered a person with sexuality' (Tilak, 1989: 40). Then, mainstream discourse about sexuality of older women, takes turn and Aunty is used as a representative of Indo-Pakistani's general (mis)perception and (mis)conception about homosexual relationships. Aunty thus becomes a mouthpiece (see 2, Table 3) to voice popular myth 'entrenched among the educated Public in modern India' who believe that homosexuality is something alien to Indians and imported to Indian soil from Euro-America (Boisvert and Johnson, 2012: 17).

The reason for such (mis)perception and (mis)conception could be traced from the ignorance of most of the people of the existence of same-sex literature in India (Kidwai and Vanita, 2001). Homosexual love needs to develop its own discourse, metaphorical traditions, terms of address and terms to distinguish it from cross-sex love. It is this void and lack which audiences have been made to observe in film Dostana. The film discourse quite adequately represents how stereotypical signifieds of love and romance fail to signify same-sex love and romance (see 3, 4, 5 in Table 3). In Table 3 above, (5) shows Sameer's attempt to narrative a same-sex love story from a woman's perspective 
because gay lovers fall short of definition of a real man. Hence, the love story of gay partners thus told creates humour through the recontextualization of cross-sex love terminology.

The intertextual and interdiscursive nature of sexuality related Indo-Pakistani discourse makes it a true representative of patriarchal and heteronormative discursive structure and social order. The discourses of family life, kinship, marriage and children make up its internal structure, fabric and core. This discourse is so naturalized, hegemonized and commonsensical that its makes same-sex relationships simply inconceivable and non-existent. In (6) Sameer gives a sexist description of a typical Indo-Pakistani mother who is emotional, sheds tears at the silliest things, always remains concerned about marriage of her children, is quite well connected with relatives and keeps an eye on all the suitable proposals for her son. Moreover, Sameer's mother's only identity in the film is that "she is a typical Indian mother". She has never been introduced with a name in the whole narrative or with any other distinguishing identity trait. Such product of heteronormative and patriarchal traditions prefers to remain oblivious to all the ideas which would shatter her comfort zone and deconstruct her supposedly natural realm of mainstream ideals and norms. She is so hegemonized that she herself declares how easy it would be for her son to choose a wife. According to Sameer's mother, Indian women are a kind of 'buffet' for her son and he can pick and choose anyone of them. Furthermore, it is also assumed that a middle class girl would not object any proposal selected for her by her elders. Thus, revelation of gay identity of her son is no less than a nightmare for such typical Indian mother (see 11, Table 3). This is why 'the act and concept of coming out as a gay person in the Indian community is for the most part unintelligible... They (homosexuals) do not desire to set themselves apart from their tribal identities and mainstream Indian society' (Gilley 2006: 66). M seems to lament the same fact in (10) and tells Officer Javier why Indian homosexuals find it almost impossible to disclose their homosexual orientation to their own parents.

Closely connected to this discussion is discourse is (12) (see Table 3) which depicts a whole picture of a common Indian household with its tradition of welcoming son's bride and the expectations about bride's faithfulness and devotion to her husband. Such religio-sociocultural traditions associated solely with heteronormativity are bound to get shattered with the advent of supposedly 'modern' trend of homosexuality among Indian diasporic youth.

Finally, the film's discourse also communicates certain characteristics of homosexual men to its presupposed heteronormative Indian audiences through Sameer and M's exclamations (see 7, 8 and 9: Table 3). Thus as communicated in (7), (8) and (9) Homosexual men:

- Do not truly reach up to the yardstick set for idealized masculinity whose extreme and violent manifestation is Gabbar (a film character who is a dacoit and takes pleasure in killing, looting and plundering), though homosexuals would never accept this general (mis)conception regarding their masculinity (7). 
- Homosexual men are more like women and less like men, because they are quite concerned about their looks and appearance (8). Such depiction of homosexuals has been achieved chiefly through effeminate mannerism of $\mathrm{M}$. His body language, cap and handbag signify these characteristics quite appropriately (8).

- Sameer advises Kunal to think like a woman and feel like a man. These lines happen when they want to hide their fear of being caught for faking gay relationship. Thus hiding the fear and showing up bravery and courage is a manly act, whereas gay mannerism is a womanly act. In such womanly act, they would adopt the body language of a woman and talk about hair and shoes (9).

All the interconnected sub-discourses and sub-texts (1-12) within grand text and discourse of film Dostana would make sense appropriately only in historical, religious and socio-cultural context of Indian sub-continent. Film's discourse seem to establish this fact that Indian diaspora despite living in foreign territories is connected its motherland India as far as practices of gender and sexuality are concerned. Still, a transnational space gives Indian diaspora liberation and agency to challenge certain cultural norms and to re-invent a system of signification in tune with its changed surroundings and discursive set-up.

\subsection{Prognostic critique}

As stated earlier, 'prognostic critique contributes to the transformation and improvement of communication' (Wodak, 2001: 64). It could be argued that somewhat similar goals of discourse analysis have also been set by Positive Discourse Analysis (Martin, 2004) which seems to praise and promote the analyzed texts. Furthermore Positive Discourse Analysis attempts to reveal detailed workings of the texts, providing a resource that can be used in the future to help design similar texts (Stibbe, 2012). Though film Dostana's text instances analyzed so far do not seem to preach tolerance for and acceptance of deviation; but film's over all thematic mood suggests otherwise and carries an inherent plea for changing one's outlook towards seemingly abhorrent and offensive ideas like same-sex relationship. This kind of change in outlook and transformation could be observed through the depiction of film's different characters who journey from negativity towards same-sex relationship to positivity:

- When Sameer and Kunal tell Aunty that they are homosexuals, she shows utter disgust at first. She faints, tries to stay away from them and does not let them touch her. After sometime, she hugs them and welcomes them in their apartment.

- Sameer's mother's final acceptance of her son's gay identity is another example of transformation and improvement of attitudes. 
- Neha does not mind befriending a gay couple and is entirely satisfied and happy with this friendship.

- Kunal at first was horrified with Sameer's idea of lying about their sexual identity, but then he is convinced living as a gay person has added so many positive things in his life like friendship and family.

- Table 4: Prognostic Critique of Film Dostana's Discourse

\section{Vocalization}

(1)Kunal to Sameer and Neha: (From1h06m42s) You know guys, you are right. I am happy and my life is truly perfect. That's only because I have two of you in my life. Think about it, If you had married somebody and you had been shooting at a beach in Miami, how would we have met? We three losers? Whatever said and done, this friendship (dostana) is much more rocking that any plan we might have had. Right?

(2)Kunal to Sameer: (from $2 \mathrm{~h} 05 \mathrm{~m} 51 \mathrm{~s}$ ) Thanks for making me a gay. This is because I became gay, I found you, I found Neha, found a friendship and a family ...

\section{Message}

Through such visual representation (see next section of the same table), modes of representation) the film seems to preach that same-sex bonding is more intense and more sincere than cross-sex bonding.

- Gay relationship should not be equated with aberration or immorality,

- Homosexual relationship could also ensure good companionship and family life like a conventional heterosexual family.

\section{Modes of Representation}

- When Kunal utters these lines, Sameer and Neha rush to hug him. At this occasion, Sameer pushes Neha aside and hugs Kunal passionately.

- Though term dostana uttered here stands for friendship between all three protagonists of the film, but visuals of the film suggest otherwise and restrict it to only male dostana.

- Subdued, soft music to represent realization.

- Visually Sameer and Kunal hug each other.

- Subdued, soft music to represent realization.

Table 4 shows a couple of instances from film's discourse which reflect transformation in Kunal's perception and his appreciation of Sameer's suggestion of faking gay relationship. Though such transformation has not been very overt, it remains implicit and inherent. There is no passionate speech in the favour of gay rights and no change in the sexual orientation of the character. It is only one visual sign (see (1), Table 4) throughout where sax-sex relationship has been given priority over cross-sex relation. Similarly, there is only one occasion where Kunal associates same-sex 
relationships with family and companionship. It must be kept in mind that such low-key plea for acceptance has been done keeping in mind mainstream heteronormative way of life of film's presupposed viewership. Still, this film should be taken as a resource that can be used in future to help formulate texts with similar message.

\section{Conclusion}

Hattatoglum (2011: 143) writes that "discourses and the way they work cannot be analyzed in isolation from the inequalities and division that shape the social space in which discourses emerge, and the power relations that stem from these inequalities and division". Hindi film discourses stem from a particular social space where gender and sexuality related inequalities and divisions are quite overt; and privileged groups are rarely interested in the process of self-examination. Thus those who "break from the fold of privileged herd to support the voices of the suppressed are usually met with great resistance and scorn" (Tarrent, 2013: 302). As this film comes from mainstream commercial genre of Hindi cinema, it attempts to avoid the scorn of mainstream audiences by unfolding the events from heteronormative male perspective. As sociodiagnostic critique of the film discourse reveals, in this film humour has been created either through recontextualization or adaptation of heteronormative religio-sociohistorical discourse practices for same sex relationship. Still, diagnostic critique of film discourse connects it with Positive Discourse Analysis (Martin, 2006) paradigm, because finally film's discourse tends to resist mainstream homophobia and inspires both privileged and unprivileged groups to demand change.

The multimodal analysis shows that in commercial or popular Hindi film discourse, heteronormativity and misogyny are common and observable phenomenon and realized through multiple signifying practices. Thus signifying practices align across all three modes (utterances, images, music) to weave film's overall system of signification. The analysis also reveals limitations or unavailability of signifying practices in mainstream Indian sub-continent discourse as for as representation of same sex relationship is concerned. Such inability to reach at the right sign is communicated chiefly through employment of paralinguistic features at important junctures. Thus, we experience confiding tones and pauses from Sameer while revealing the orientation of his and Kunal's relationship, Aunty and mothers' fainting at the discovery of Sameer and Kunal's gay identity and so on. At many occasions, characters struggles to reach some appropriate signifiers and hope that their tone would communicate the intended message. Similarly, derogatory use of feminine tone, female point of view and effeminate body language for narration of gay love story could be understood through experiencing intricate web of film's complete multimodal fabric.

The present study has focused on critique of gender and sexuality related signifying practices of film Dostana in relation to discourse's three interrelated aspects, i.e. immanent, socio-diagnostic and prognostic. This is a humble effort to explore some of the aspects and signifying practices of complex multimodal texts like film. There are 
still many related and connected questions waiting to be explored by future researchers; for example, how do audiences make sense of interrelated and interdependent signifying practices, and how could Hindi film songs along with their mass oriented verbal and visual content contribute in (re)constructing audiences' mental model regarding gender roles and sexual orientation.

\section{References}

Baldry, Anthony (2004): "Concordancing film corpora: the role of MCA in multimodal discourse analysis". In C. Taylor, M. G. Busà and S. Gesuato, eds.), Proceedings of the Seminar, Linguatel: Progetto telematico di lingua e mediazione interlinguistica, 9-10 May 2002 - University of Padua: Padova.

Baldry, Anthony and Thibault, Paul (2001): "Towards multimodal corpora". In G. Aston and L. Burnard, eds., Corpora in the Description and Teaching of English. Bologna: CLUEB, 87102.

Barthes, Roland (1991): Mythologies. New York: The Noonday Press.

Bhattacharya, Nandini (2013): Hindi Cinema: Repeating the Subject. New York: Routledge.

Blackledge, Adrian (2005): Discourse and Power in a Multilingual World. Philadelphia and Amsterdam: John Benjamins.

CADAAD (2014): Retrieved December 19, 2014. http: //cadaad.net/news/

Cheng, Patrick S. (2014): "Contributions from Queer Theory". In A. Thatcher, ed., The Oxford Handbook of Theology, Sexuality, and Gender. Oxford: Oxford University Press, 153-169.

Desai, Jigna and Neutill, Rani (2013): The Anxieties of 'New' Indian Modernity. In A. Quayson and G. Deswani, eds., A Companion to Diaspora and Transnationalism, Oxford: Blackwell, 231-248.

Dostana (2008): Dharma Productions: Mumbai.

Dosti (1964): Rajshiri Productions: Mumbai.

Durdah, Rajinder and Dudrah, Rajinder Kumar (2012): Bollywood Travels: Culture, Diaspora and Border Crossings in Popular Hindi Cinema. New York: Routledge.

Fairclough, Norman (1992): Discourse and Social Change. Cambridge: Polity Press.

Fairclough, Norman (2001): Language and Power. London: Longman.

Foucault, Michael (1972): The Archaeology of Knowledge. London: Tavistock.

Foucault, Michael (1978): The History of Sexuality. Harmondsworth: Allen Lane/Penguin.

Foucault, Michael (1980): Power/Knowledge. Brighton: Harvester.

Gilley, Brian J (2006): Becoming Two-spirit: Gay Identity and Social Acceptance in Indian Country. Lincoln, Nebraska: University of Nebraska Press.

Hall, Stuart (1997): Representation: Cultural representations and signifying practices. London: Sage, Open University Press.

Halperin, David (1997): Saint Foucault: Towards a Gay Hagiography. New York: Oxford University Press.

Hattatoglu, Dilek (2011): "Gender and Labor within the Turkish Context of Local Development in the Era of Globalization”. In E. N. Chow, M. T. Segal, L. Tan, eds., Analyzing Gender, Intersectionality, and Multiple Inequalities: Global, Transnational and Local Contexts (Advances in Gender Research, Volume 15), Bingley, UK: Emerald, 139-159. 
Jorgensen, Marianne and Phillips, Louise J. (2002): Discourse Analysis as Theory and Method. London: Sage.

Kasbekar, Asha (2006): Pop Culture India: Media, Arts, and Lifestyle. California: ABC-CLIO.

Kaur, Raminder and Sinha, Ajay (2005): Bollywood: Popular Indian Cinema Through A Transnational Lens. New Delhi: Sage.

Kress, Gunther and Van Leeuwen, Theo (2006): Reading Images: Grammar of Visual Design. New York: Routledge.

Lazar, Michelle M. (2007): "Feminist Critical Discourse Analysis: Articulating a Feminist Discourse Praxis". Critical Discourse Studies 4(2): 141-164.

Martin, James (2004): "Positive Discourse Analysis: Solidarity and Change". Revista Canaria de Estudios Ingleses 49: 179-200.

Morcom, Anna (2007): Hindi film songs and the cinema, Berlingtion: Ashgate.

O'Halloran, Kay L. (2004): Multimodal Discourse Analysis, Systemic Functional Perspectives, Open Linguistics Series: Continuum.

O'Halloran, Kay L. (2005): Mathematical Discourse: Language, Symbolism and Visual Images. London and New York: Continuum.

O'Halloran, Kay L. and Smith, B. A. (eds.) (2011): Multimodal Studies: Exploring Issues and Domains. New York and London: Routledge.

O’Toole, Lawrence M. (1994): The Language of Displayed Art. London: Leicester University Press.

Rasche, Rebecca (2006): American Film Comedies. Seminar paper. Available at http: //books.google.at/ \& www.grin.com

Richardson, John E. and Wodak, Ruth (2009a): "Recontextualizing fascist ideologies of the past: Right-wing discourses on employment and nativism in Austria and the United Kingdom”. Critical Discourse Studies 6 (4): 251-267.

Richardson, John E. and Wodak, Ruth. (2009b): "The impact of visual racism: Visual arguments in political leaflets in Austrian and British far-right parties". Controversia 6 (2): 45-67.

Sholay (1975): Mumbai: Sippy Films.

Srinivasan, Rama (2013): "Queer Times in Bollywood". In M. Gokulsing and W. Dissanayake, eds., Routledge Handbook of Indian Cinemas. New York: Routledge.

Stibbe, Arran (2013): "The Corporation as Person and Psychopath: Multimodal Metaphor, Rhetoric and Resistance". Critical Approaches to Discourse Analysis across Disciplines http: //cadaad.net/journal Vol. 6 (2): 114-136.

Tarrent, Shira (2013): Men Speak Out. Views on Gender, Sex and Power. New York: Routledge.

Tilak, Shirinivas (1989): Religion and Aging in Indian Tradition. New York: SUNY Press.

van Dijk, Teun (ed.) (1997): "Introduction" in Discourse as Structure and Process: A Multidisciplinary Introduction. Vol. 1. London: Sage.

van Leeuwen, Theo (1993): "Genre and field in critical discourse analysis: a synopsis". Discourse \& Society 4(2): 193-223.

Vanita, Ruth and Kidwai, Saleem (ed.) (2001): Same-Sex Love in India: Readings from Literature and History. Basingstoke: Palgrave Macmillan.

Wodak, Ruth and Reisigl, Martin (1999): "Discourse and Racism: European Perspectives". Annual Review of Anthropology 28: 175-199.

Wodak, Ruth (2001): "Discourse Historical Approach". In R. Wodak and M. Meyer, eds., Methods of Critical Discourse Analysis. London: Sage. 
Wodak, Ruth and Meyer, Michael (2009): "Critical Discourse Analysis: History, agenda, theory and methodology". In R. Wodak and M. Meyer, eds., Methods of Critical Discourse Analysis. London: Sage, 1-34. 